\section{$\underset{\substack{\text { hommes } \\ \text { \& migrations }}}{ }$}

\section{Hommes \& migrations}

Revue française de référence sur les dynamiques

migratoires

\section{$1283 \mid 2010$}

\section{Cuisines et dépendances}

\title{
Le dernier vol
}

Film français de Karim Dridi

\section{André Videau}

\section{Q OpenEdition \\ 1 Journals}

\section{Édition électronique}

URL : http://journals.openedition.org/hommesmigrations/1022

DOI : 10.4000/hommesmigrations. 1022

ISSN : 2262-3353

\section{Éditeur}

Musée national de l'histoire de l'immigration

\section{Édition imprimée}

Date de publication : 1 janvier 2010

Pagination : 196

ISBN : 978-2-919040-04-9

ISSN : $1142-852 X$

\section{Référence électronique}

André Videau, «Le dernier vol », Hommes \& migrations [En ligne], 1283 | 2010, mis en ligne le 29 mai

2013, consulté le 22 septembre 2020. URL : http://journals.openedition.org/hommesmigrations/1022 ; DOI : https://doi.org/10.4000/hommesmigrations.1022

Ce document a été généré automatiquement le 22 septembre 2020.

Tous droits réservés 


\title{
Le dernier vol
}

\author{
Film français de Karim Dridi
}

\section{André Videau}

1 Ah ! la belle et pathétique aventure ! Il n'y manque pas un grain de sable ni un poil de chameau. Pas un baiser ni une larme. Pas un méchant Touareg en embuscade ni un valeureux goumier prêt à faire parler la poudre. On est dans les années trente, autour d'un bivouac colonial français et dans l'adaptation d'un roman de Sylvain Estibal : Le dernier vol de Lancaster (Actes Sud, 2003). On est aussi au cœur de l'inhospitalier et sublime Ténéré où les tempêtes menacent. On devine, prête à se déchaîner, la rivalité entre le militaire de carrière ("mon capitaine" Vincent Brousseau - Frédéric Epard), psycho-rigide sous sa jugulaire, et le lieutenant Antoine Chaumet (le beau Guillaume Canet), militaire d'occasion, irrésistible dans ses révoltes.

2 Tout est en place pour l'atterrissage de Marie Vallières de Beaumont (sic et ressic !). La môme Marion Piaf Cotillard, auréolée de gloire hollywoodienne, descend de son biplan, folle d'inquiétude. Son fiancé Bill Lancaster, pilote anglais émérite qui effectuait la traversée Londres-Le Cap, a disparu dans les dunes. Les deux hommes forts du poste vont s'opposer et étaler leurs faiblesses.Tous les ingrédients sont réunis pour une tragédie héroïque.

On se demande quelle mouche a piqué Karim Dridi et anesthésié son sens critique, face à cette production un peu dépourvue de moyens et pourtant alourdie de performances aéronautiques et de nostalgies coloniales. Peut-être fut-il guidé par le souvenir ému de lectures adolescentes : rayon Signes de Piste ou Bibliothèque verte, genre odyssées de l'aéropostale, expéditions africaines, exploits de "conquête", de "pacification". Ou encore transporté du côté des romans démodés de Joseph Peyré, Joseph Kessel, Jean d'Esme ou Roland Dorgelès, des films de Duvivier, Delannoy ou Dréville... Ce ne serait pas la première fois que le cinéaste français d'origine tunisienne s'amuserait à brouiller les cartes, s'inscrirait à contre-courant et cultiverait une posture que l'on n'attend pas. Il a toujours revendiqué la plus grande liberté dans le choix de ses sujets (la boxe, la musique cubaine - Cuba Feliz, 2000 ; les gitans - Khamsa, 2008 ; les comédiens - Hors jeu, 1998...). Depuis le succès inégalé de Bye-bye, (1996), il refuse de se laisser enfermer dans une catégorie, le cinéma beur, dont il réfute l'existence, même si, paradoxalement, 
il lui a donné ses lettres de noblesse avec son personnage principal, interprété par Sami Bouajila, qui casse les stéréotypes (le comédien se montrant lui aussi capable de s'évader d'un répertoire ethnicisé). Si ce film n'est qu'une nouvelle récréation, ou une provocation, on peut attendre sereinement la prochaine fantaisie de Karim Dridi, en souhaitant qu'elle vise un peu plus juste. 